\title{
Simulating and delineating future land change trajectories across Europe
}

\author{
Julia Stürck ${ }^{1}$ - Christian Levers ${ }^{2}$ Emma Henriëtta van der Zanden ${ }^{1}$ • \\ Catharina Johanna Elizabeth Schulp ${ }^{1} \cdot$ Pieter Johannes Verkerk $^{3}$. \\ Tobias Kuemmerle $^{2,4} \cdot$ John Helming ${ }^{5}$ Hermann Lotze-Campen ${ }^{4,6}$. \\ Andrzej Tabeau $^{5} \cdot$ Alexander Popp $^{6} \cdot$ Elizabeth Schrammeijer $^{1} \cdot$ Peter Verburg $^{1}$
}

Received: 9 December 2014/Accepted: 21 September 2015/Published online: 17 November 2015

(C) The Author(s) 2015. This article is published with open access at Springerlink.com

\begin{abstract}
Explorations of future land use change are important to understand potential conflicts between competing land uses, trade-offs associated with particular land change trajectories, and the effectiveness of policies to steer land systems into desirable states. Most model-based explorations and scenario studies focused on conversions in broad land use classes, but disregarded changes in land management or focused on individual sectors only. Using the European Union (EU) as a case study, we developed an approach to identifying typical combinations of land cover
\end{abstract}

Electronic supplementary material The online version of this article (doi:10.1007/s10113-015-0876-0) contains supplementary material, which is available to authorized users.

\section{Julia Stürck}

julia.sturck@vu.nl

Christian Levers

christian.levers@geo.hu-berlin.de

Emma Henriëtta van der Zanden

emma.vander.zanden@vu.nl

Catharina Johanna Elizabeth Schulp

nynke.schulp@vu.nl

Pieter Johannes Verkerk

hans.verkerk@efi.int

Tobias Kuemmerle

tobias.kuemmerle@geo.hu-berlin.de

John Helming

john.helming@wur.nl

Hermann Lotze-Campen

lotze-campen@pik-potsdam.de

Andrzej Tabeau

andrzej.tabeau@wur.nl

Alexander Popp

popp@pik-potsdam.de and management changes by combining the results of multimodel simulations in the agriculture and forest sectors for four scenarios from 2000 to 2040 . We visualized land change trajectories by mapping regional hotspots of change. Land change trajectories differed in extent and spatial pattern across the EU and among scenarios, indicating trajectory-specific option spaces for alternative land system outcomes. In spite of the large variation in the area of change, similar hotspots of land change were observed among the scenarios. All scenarios indicate a stronger polarization of land use in Europe, with a loss of multifunctional landscapes. We analyzed locations subject to change by comparing location characteristics associated

\section{Elizabeth Schrammeijer}

bep@messd.org

Peter Verburg

peter.verburg@vu.nl

1 Department of Earth Sciences, VU University Amsterdam, De Boelelaan 1087, 1081 HV Amsterdam, The Netherlands

2 Geography Department, Humboldt-Universität zu Berlin, Unter den Linden 6, 10099 Berlin, Germany

3 European Forest Institute, Yliopistokatu 6, 80100 Joensuu, Finland

4 Integrative Research Institute on Transformations in HumanEnvironment Systems (IRI THESys), Humboldt-Universität zu Berlin, Unter den Linden 6, 10099 Berlin, Germany

5 Agricultural Economics Research Institute LEI, Wageningen University and Research Centre, Post box 29703, 2502 LS The Hague, The Netherlands

6 Potsdam Institute for Climate Impact Research (PIK), Telegrafenberg A 31, 14473 Potsdam, Germany 
with certain land change trajectories. Results indicate differences in the location conditions of different land change trajectories, with diverging impacts on ecosystem service provisioning. Policy and planning for future land use needs to account for the spatial variation of land change trajectories to achieve both overarching and location-specific targets.

Keywords Land use change - Land system - Modeling · Scenario $\cdot$ Europe $\cdot$ Ecosystem service

\section{Introduction}

Land systems undergo constant change in response to a wide array of economic, environmental, institutional, and societal drivers (Geist et al. 2006; van Vliet et al. 2015). In recent decades, population growth and changing consumption patterns have led to a worldwide expansion and intensification of land use, potentially increasing the pressure on natural systems and the ecosystem services they provide (DeFries et al. 2004; Millenium Ecosystem Assessment 2005; Lambin and Meyfroidt 2011). These trends will likely continue in the future, as demand for land-based goods and services will increase drastically due to population growth, more meat-based diets, and a growing role of bioenergy (Lotze-Campen et al. 2010; UNECE-FAO 2011; Alexandratos and Bruinsma 2012). Understanding the land use outcomes of these trends is important (Rounsevell et al. 2012).

Substantial uncertainty exists as to how land use patterns in particular regions will change due to these trends. A range of location factors, including environmental conditions (e.g., topography, soil fertility), socioeconomic settings (e.g., distribution of income), spatial planning (e.g., nature conservation), as well as policies and trade, all exert strong influences in shaping land use responses to changing demands. Exploring future land use patterns is critical for anticipating possible negative impacts, identifying potential conflicts between competing land functions, and developing sustainable land use strategies to mitigate these (Verburg et al. 2006; Fürst et al. 2013; Seppelt et al. 2013). Land use modeling based on salient, credible, and legitimate storylines is a fundamental tool for exploring possible futures of land use change (Brown et al. 2013), and a wide range of models is currently available (Sleeter et al. 2012; Mas et al. 2014; Tayyebi et al. 2014).

Most studies to date have focused only on transitions among broad land cover classes (e.g., the conversion of forest into agriculture; Ramankutty and Foley 1999; Sohl and Sayler 2008; Verburg et al. 2009), while more subtle land use changes are omitted. Globally, and particularly in Europe, however, not only drastic land conversions, but specifically widespread land management changes constituted for a large share of land use change over the last decades (Stoate et al. 2001; Erb et al. 2013; Kuemmerle et al. 2013). Moreover, land management change impacts ecosystem service provisioning and biodiversity in substantial ways (Tscharntke et al. 2005), yet despite these possibly large impacts, land management change remains understudied (Erb et al. 2013; Luyssaert et al. 2014). Additionally, there are important feedbacks between land cover conversions and management changes. For example, changes in the management intensity influence yields and thus the required area for that land use (Matson and Vitousek 2006). Moreover, land management changes in forests and agricultural systems are often addressed separately and not integrated within the landscape context (Rounsevell et al. 2012). For a comprehensive interpretation of land change, it is essential to integrate land management change into land change modeling studies.

Identical local land cover or land management changes can have different drivers and consequences in different contexts or at different scales of analysis. For example, locally, the conversion of cropland to forest can indicate land abandonment and a decrease in the importance of agriculture. At the regional scale, however, such conversions may be associated with intensification of land management on more suitable locations and, thus, a polarization of rural land use (Plieninger et al. 2014). This illustrates how the consideration of multiple scales during the analysis can help to address and disentangle multiple land change trajectories and deepen the insights gained from land use change scenarios. Approaches that assess land use change at various scales and that jointly consider land cover and management changes are needed. The cooccurrence of different land change trajectories in the European Union (EU) has led to concerns for policy and planning (Renwick et al. 2013; van Zanten et al. 2014). This study focusses on identifying potential future land change trajectories for the EU.

The objective of this study was to integrate and interpret the results of consistent, multimodel, scenario simulations of both land cover and land management change in terms of typical land change trajectories at the extent of the EU. First, we create a typology of different land change trajectories based on the extent and regional patterns of simulated land use change. Second, we explore the complexity of interacting land use changes across scales for four alternative scenarios of land use change between 2000 and 2040. Third, we characterize the locations which are affected by particular land change trajectories in terms of their location characteristics and discuss the potential consequences of future land change in terms of their impact on current levels of ecosystem service provision. 


\section{Materials and methods}

We integrated the results of a suite of models which account for demographic, economic, and environmental drivers across the EU (excluding Croatia) to map both land cover and land management change (Sect. 2.1). We then developed a typology of land change trajectories and summarized hotspots of occurrence of these land change trajectories across the EU following an expert-based hierarchical approach (Sect. 2.2). Finally, we analyzed the location characteristics of areas affected by land change trajectories (Sect. 2.3).

\section{Land cover and land management scenarios}

We simulated land use change in Europe between the years 2000 and 2040 for a set of exploratory scenario storylines that reflect socioeconomic, cultural, political, and technological changes in the EU. The four scenario storylines follow closely the IPCC SRES framework (Nakicenovic et al. 2000), but the drivers were modified to represent the conditions specific to the EU and were supplemented with conditions that address land use change in the European context. Importantly, our scenarios differed in their degree of regionalization versus globalization, and the extent of policy intervention (Table 1). Detailed scenario storylines are found in the Supplementary Material, Annex A.

To implement these storylines in simulations of future land cover and land management, we used a chain of models that exchange information in a top-down, hierarchical manner (Fig. 1). By implementing scenario conditions (Table 1), global models calculated changes in gross domestic product, required areas for food, feed and bioenergy crops, and wood production (Kallio et al. 2004; Lotze-Campen et al. 2008; Luderer et al. 2013; Woltjer and Kuiper 2014). The simulations from these global models were fed into different regional models that calculated urban land demand, crop-specific fertilizer use, livestock numbers, and potential supply of woody biomass from European forests at the national or subnational level (Britz and Witzke 2012; Lotze-Campen et al. 2014; Sallnäs 1990; Schelhaas et al. 2007; Verkerk et al. 2011). We then disaggregated the simulation outcomes to the grid level $\left(1 \mathrm{~km}^{2}\right)$ using a land cover allocation model at yearly time steps from 2000 to 2040. Land cover was represented in 16 land cover categories (Table S2). A detailed description of the land cover allocation procedure can be found in Verburg and Overmars (2009).

Indicators for the management intensity of cropland, pastures, and forests were derived from the sectorial model outputs. To create maps of management intensity of cropland, we used nitrogen-based fertilizer use as a proxy.
Table 1 Scenario storylines

\begin{tabular}{ll}
\hline Scenario & Storyline \\
\hline $\begin{array}{l}\text { Libertarian Europe } \\
\text { (V-A1) }\end{array}$ & $\begin{array}{l}\text { Globalizing world with strong economic } \\
\text { growth } \\
\text { Global free trade } \\
\text { Moderate population growth }\end{array}$ \\
& Absent or weak regulation policies \\
& No climate change adaptation and mitigation \\
Eurosceptic Europe & Fragmented world with modest economic \\
(V-A2) & growth \\
& Trade protectionism \\
& Strong population growth \\
& Weak regulation of land use change \\
& No climate change adaptation and mitigation \\
Sustainable world with modest economic & growth \\
Europe (V-B1) & Global free trade \\
& Modest population growth \\
& Strong policy interventions \\
Global implementation of ecosystem service \\
(V-B2) \\
concepts and treaties for climate change \\
adaptation and mitigation \\
Fragmented world with modest economic \\
growth \\
Regional markets \\
Modest population growth \\
Moderate policy intervention \\
Environmental objectives are implemented \\
regionally \\
\hline
\end{tabular}

Nitrogen input links to agro-biodiversity and is therefore often used as a proxy for agricultural intensity (Overmars et al. 2014). We disaggregated fertilizer use $(\mathrm{kg} / \mathrm{ha})$ at NUTS2 level to the $1 \mathrm{~km}^{2}$ grid following the approach of Temme and Verburg (2011), implemented for the full EU territory by Overmars et al. (2014). This disaggregation assigned a level of land use intensity to all cropland: low $(0-50 \mathrm{~kg} / \mathrm{ha})$, moderate $(>50-150 \mathrm{~kg} / \mathrm{ha})$, and high $(>150 \mathrm{~kg} / \mathrm{ha}$ ) fertilizer use (Fig. 1). We used grazing intensity of cattle, goats, and sheep as a proxy for nitrogen inputs on pastures as suggested by Temme and Verburg (2011). We converted livestock numbers on NUTS2 level to livestock units (LSU) following Neumann et al. (2009). We disaggregated LSU to livestock density $\left(\mathrm{LSU} / \mathrm{km}^{2}\right.$ ) based on grazing probability maps (Neumann et al. 2009) and reclassified the result into two classes, which were used as a proxy for low $\left(0-25 \mathrm{LSU} / \mathrm{km}^{2}\right)$ and high $(>25 \mathrm{LSU} /$ $\mathrm{km}^{2}$ ) grazing intensity (Fig. 1).

For forest management, we used wood removals, which reflect the use intensity of forests. Other aspects of forest management, such as species composition and stand age, were not addressed with this approach (Schall and Ammer 


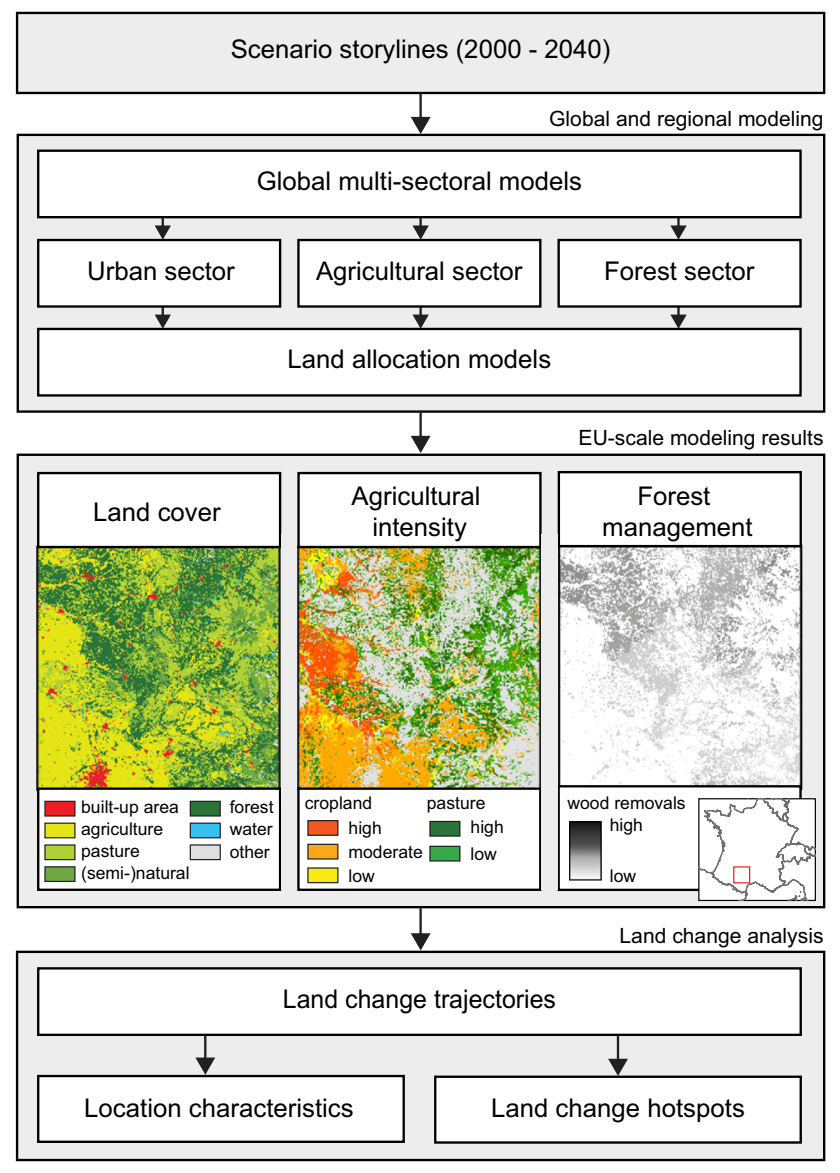

Fig. 1 Overview of modeling chain and analysis

2013). Wood removals $\left(\mathrm{m}^{3} / \mathrm{ha} /\right.$ year $)$ were projected with EFISCEN on subnational level (Verkerk et al. 2014). We applied a disaggregation approach (Elbersen et al. 2012) using tree species maps (Brus et al. 2011), harvest likelihood maps (Verkerk et al. 2015), and forest cover maps as simulated for the scenarios by the Dyna-CLUE model. Wood removals were only available for time steps which covered the years 2010 onwards. We assumed wood removals to be constant between 2000 and 2010 and interpolated volumes of wood removals in 2010 for forest extent in 2000 (Fig. 1). Detailed information on the linked modeling system is found in Lotze-Campen et al. (in preparation for this issue) and in the Supplementary Material, Annex B.

\section{Land change trajectories}

We identified land change trajectories which (1) represent well-known and significant land change trends in Europe, (2) make optimal use of the simulation results of the available models, and (3) cover all possible land conversions on the grid level modeled with Dyna-CLUE (Table 2). An overview of all identified land change trajectories is found in Table 3. Each land change trajectory can be characterized by two dimensions: (1) The increasing or decreasing human impact a land change trajectory may have on the landscape and (2) the spatial extent of the landscape relevant to the trajectory, i.e., the role of landscape neighborhood on the locally identified land use change (Fig. 2). Within each scenario simulation, we assigned each pixel that was not stable over time to one or more land change trajectories according to classification rules of varying complexity (Fig. 3).

Most land change trajectories can be identified by consideration of local variables only, for example intensity changes and land cover conversions such as land abandonment. Other trajectories required additional information, for example urban and peri-urban growth. Here, in a first step, urban cores and peri-urban belts are delineated for the scenarios in 2040, and in a second step, growth of built-up areas is classified to urban or peri-urban growth based on these masks. For the identification of the trajectory expansion of wild areas, first, wild areas were defined and delineated for 2000 and scenarios in 2040. Both land abandonment and reduced wood removals in forests within expanding wild areas were considered as contributions to the expansion of wild areas. For the trajectory polarization of rural land, the conjoint occurrence of land abandonment and intensification of agriculture were identified. For this, we masked the land abandonment trajectory with a focal map representing areas with contracting agriculture and the cropland and pasture intensification trajectories with focal maps representing areas where, on average, management intensified. These steps were taken to make sure that the land abandonment and intensification grid cells found were representative for the changes in the considered regions and were not counteracted by other developments. A full description of procedures used to delineate land change trajectories from the modeling results is found in the supplementary material, Annex C.

The delineation of land change hotspots facilitates the identification of drastic change events and allows for factoring in regional conditions and processes to contextualize land changes. As such, the identification of hotspots is valuable for prioritization of land use planning and policies. We delineated hotspots of occurrence (top $10 \%$ quantile) for each of the considered land change trajectories (Fig. 4). We chose a uniform moving window of $15-\mathrm{km}$ radius for hotspot delineation. This extent was chosen to allow reflecting regional-scale land changes, without omitting too much spatial detail. First, we quantified the relative extent of a land change trajectory within the specified neighborhood. Upon a decrease in a particular land use, for example, through land abandonment, we then calculated the relative extent of agricultural land within each neighborhood in the reference year and used this value to weight the relative extent of land abandonment within the specified neighborhood. 
Table 2 Land cover changes in Dyna-CLUE and associated land change trajectories delineated in this study

\begin{tabular}{|c|c|c|c|c|c|}
\hline & \multicolumn{5}{|c|}{ Land cover in year 2040} \\
\hline & Built-up & Cropland & Pasture & (Semi)Natural & Forest \\
\hline \multicolumn{6}{|c|}{ Land cover in year 2000} \\
\hline Built-up & Stability & - & - & - & - \\
\hline Cropland & $\begin{array}{l}\text { Urban growth } \\
\text { Peri-urban growth }\end{array}$ & $\begin{array}{l}\text { Stability } \\
\text { De-intensification } \\
\text { Intensification } \\
\text { Polarization of rural land }\end{array}$ & Cropland to pasture & $\begin{array}{l}\text { Land abandonment } \\
\text { Polarization of rural } \\
\text { land } \\
\text { Expansion of wild } \\
\text { areas }\end{array}$ & $\begin{array}{l}\text { Land abandonment } \\
\text { Polarization of rural } \\
\text { land } \\
\text { Expansion of wild } \\
\text { areas }\end{array}$ \\
\hline Pasture & $\begin{array}{l}\text { Urban growth } \\
\text { Peri-urban growth }\end{array}$ & Recultivation of pasture & $\begin{array}{l}\text { Stability } \\
\text { De-intensification } \\
\text { Intensification } \\
\text { Polarization of rural land }\end{array}$ & $\begin{array}{l}\text { Land abandonment } \\
\text { Polarization of rural } \\
\text { land } \\
\text { Expansion of wild } \\
\text { areas }\end{array}$ & $\begin{array}{l}\text { Land abandonment } \\
\text { Polarization of rural } \\
\text { land } \\
\text { Expansion of wild } \\
\text { areas }\end{array}$ \\
\hline $\begin{array}{l}\text { (Semi- } \\
\text { )Natural }\end{array}$ & $\begin{array}{l}\text { Urban growth } \\
\text { Peri-urban growth } \\
\text { Contraction of wild } \\
\text { areas }\end{array}$ & $\begin{array}{l}\text { Recultivation of green } \\
\text { space } \\
\text { Contraction of wild areas }\end{array}$ & $\begin{array}{l}\text { Recultivation of green } \\
\text { space } \\
\text { Contraction of wild areas }\end{array}$ & Stability & $\begin{array}{l}\text { Contraction of wild } \\
\text { areas }\end{array}$ \\
\hline Forest & $\begin{array}{l}\text { Urban growth } \\
\text { Peri-urban growth } \\
\text { Contraction of wild } \\
\text { areas }\end{array}$ & $\begin{array}{l}\text { Recultivation of green } \\
\text { space } \\
\text { Contraction of wild areas }\end{array}$ & $\begin{array}{l}\text { Recultivation of green } \\
\text { space } \\
\text { Contraction of wild areas }\end{array}$ & - & $\begin{array}{l}\text { Stability } \\
\text { De-intensification } \\
\text { Intensification } \\
\text { Contraction of wild } \\
\text { areas }\end{array}$ \\
\hline
\end{tabular}

This leads to the accentuation of areas (1) where land abandonment occurs frequently within the specified neighborhood and (2) whose neighborhoods were dominated by agriculture in the reference year. To make sure we only considered neighborhoods where land abandonment was not offset by agricultural expansion, only grid cells with contracting agriculture cover in their neighborhoods are eligible for the hotspot delineation (Fig. 4). A full description of procedures used to delineate land change hotspots from the modeling results is found in the supplementary material, Annex C. We mapped all hotspots of land change trajectories per land use scenario (Fig. 8). As land change trajectories can overlap (for example, land abandonment and polarization of rural land), we implemented a visualization hierarchy based on Fig. 3 and gave mapping priority with increasing complexity and increasing human impact of a given land change trajectory.

\section{Location characteristics of land change trajectories}

We used six indicators which represent ecosystem service provision and other location characteristics to portray locations where particular land changes occur in the future scenarios (hereafter referred to as location characteristics). Doing so reveals the potential impact of a particular land change trajectory on an affected location and may indicate threats and benefits for human well-being. All indicators were available on a $1 \mathrm{~km}^{2}$ grid across the EU and reflected the state around the year 2000 .

\section{Carbon sequestration}

Carbon sequestration describes the uptake of atmospheric carbon dioxide in soil and biomass. Sequestration rates are region-specific and depend on land cover and land use, forest age, soil, and the amount of carbon which is already present in the soil. In this study, carbon sequestration was expressed as carbon stock changes per $\mathrm{km}^{2}$ per year $(\mathrm{Mg}$ $\mathrm{C} \mathrm{km}^{-2}$ year $^{-1}$ ) following Schulp et al. (2008).

\section{Erosion risk}

Soil erosion risk is a disservice that depends on land cover and land use, soil erodibility, topography, and rainfall regime. Here, the indicator developed by Pérez-Soba et al. (2010) was based on the Universal Soil Loss Equation (Wischmeyer and Smith 1978). Erosion risk is given in tons per hectare at a $1 \mathrm{~km}^{2}$ resolution.

\section{Nature-based tourism}

Nature-based tourism addresses the capacity of the ecosystem to support recreation and tourism (e.g., winter 
Table 3 Overview of land change trajectories and the rules used for detection

\begin{tabular}{|c|c|c|}
\hline Land change trajectory name & Short description & Classification rules \\
\hline Stability & $\begin{array}{l}\text { No change in land cover nor land } \\
\text { management intensity }\end{array}$ & $\begin{array}{l}\text { Grid cells covered by a dynamic land cover category (built-up } \\
\text { area, arable land (incl. permanent crops), pasture, (semi- } \\
\text { )natural land, and forest) in the reference year, for which } \\
\text { neither land cover nor management intensity changed in the } \\
\text { scenarios }\end{array}$ \\
\hline \multirow[t]{2}{*}{$\begin{array}{r}\text { Intensification and } \\
\text { de-intensification }\end{array}$} & $\begin{array}{l}\text { Change in land management } \\
\text { intensity }\end{array}$ & $\begin{array}{l}\text { Increase or decrease of (a) fertilizer use on arable land } \\
\text { (b) grazing intensity on pastures (c) wood removals in } \\
\text { forests. All grid cells which had a higher (lower) intensity } \\
\text { category than the reference year were considered intensifying } \\
\text { (de-intensifying) }\end{array}$ \\
\hline & & $\begin{array}{l}\text { Changes in wood removals of more than } 25 \% \text { compared to the } \\
\text { reference year were considered intensifying or de- } \\
\text { intensifying }\end{array}$ \\
\hline Expansion and decline & Land cover conversions & $\begin{array}{l}\text { Land cover that converted to another land cover category on } \\
\text { the grid level }\end{array}$ \\
\hline Land abandonment & $\begin{array}{l}\text { Conversion of agriculture to green } \\
\text { space }\end{array}$ & $\begin{array}{l}\text { Conversion of agriculture (i.e., arable land and pasture) in the } \\
\text { reference year to green space (i.e., forest or (semi-)natural } \\
\text { vegetation) }\end{array}$ \\
\hline Arable land to pasture & $\begin{array}{l}\text { Conversion of arable land to } \\
\text { pasture }\end{array}$ & Conversion of arable land in the reference year to pasture \\
\hline Recultivation of green space & $\begin{array}{l}\text { Conversion of green space to } \\
\text { agriculture }\end{array}$ & $\begin{array}{l}\text { Grid cells covered by green space (i.e., forest or (semi-)natural } \\
\text { vegetation) in the reference year converted into agriculture }\end{array}$ \\
\hline Recultivation of pasture & $\begin{array}{l}\text { Conversion of pasture to arable } \\
\text { land }\end{array}$ & $\begin{array}{l}\text { Grid cells covered by pasture in the reference year converted to } \\
\text { arable land }\end{array}$ \\
\hline Polarization of rural land & $\begin{array}{l}\text { Parallel land abandonment and } \\
\text { intensification in remaining } \\
\text { agriculture patches }\end{array}$ & $\begin{array}{l}\text { Grid cells which display land abandonment or agricultural } \\
\text { intensification in regions where agricultural area declined and } \\
\text { agricultural intensity increased within a radius of } 15 \mathrm{~km}\end{array}$ \\
\hline Urban growth & $\begin{array}{l}\text { Growth of built-up area which } \\
\text { adds to an urban core }\end{array}$ & $\begin{array}{l}\text { Expansion of built-up area was only identified as urban growth } \\
\text { if it led to the expansion of an urban core in immediate } \\
\text { adjacency. Urban cores were derived from DGUR (degree of } \\
\text { urbanization typology) available from Eurostat (2001) and } \\
\text { merged with the extent of built-up area in the reference year } \\
\text { to distinguish urban agglomerations from other built-up areas }\end{array}$ \\
\hline Peri-urban growth & $\begin{array}{l}\text { Growth of built-up area located in } \\
\text { the rural-urban fringe }\end{array}$ & $\begin{array}{l}\text { New built-up area located within the expanding rural-urban } \\
\text { fringe in a scenario was addressed as peri-urban growth. The } \\
\text { rural-urban fringe was identified as the area between the } \\
\text { outskirts of an urban agglomeration and the countryside. We } \\
\text { varied the size of the rural-urban fringe with respect to the } \\
\text { size of the urban cores by using a diameter of twice the radius } \\
\text { of the urban core to delineate the extent of the rural-urban } \\
\text { fringe. When an urban core expanded in a scenario, its } \\
\text { associated rural-urban fringe expanded proportionally }\end{array}$ \\
\hline Expansion of wild areas & $\begin{array}{l}\text { Conversion of agriculture and } \\
\text { intensively managed forest to a } \\
\text { more natural vegetation cover, } \\
\text { adding to contiguous patches of } \\
\text { nature }\end{array}$ & $\begin{array}{l}\text { Grid cells which contributed to the growth of wild areas were } \\
\text { considered expansion of wild areas. Wild areas were defined } \\
\text { as contiguous patches of nature larger than } 1000 \mathrm{~km}^{2} \text { (Wild } \\
\text { Europe 2013). Nature could comprise all land cover which } \\
\text { was not covered by built-up area, agriculture, pasture, and } \\
\text { intensively managed forest. Nature in adjacency to built-up } \\
\text { area or agriculture was not considered eligible as a part of } \\
\text { wild area. Only patches of wild area which showed net } \\
\text { growth were considered }\end{array}$ \\
\hline Contraction of wild areas & $\begin{array}{l}\text { Conversion of wild areas to built- } \\
\text { up area, agriculture or high } \\
\text { intensity forest }\end{array}$ & $\begin{array}{l}\text { Grid cells which were part of wild areas in the reference year } \\
\text { and converted to built-up area, agriculture, or intensively } \\
\text { managed forest during a scenario were considered as } \\
\text { contraction of wild areas }\end{array}$ \\
\hline
\end{tabular}




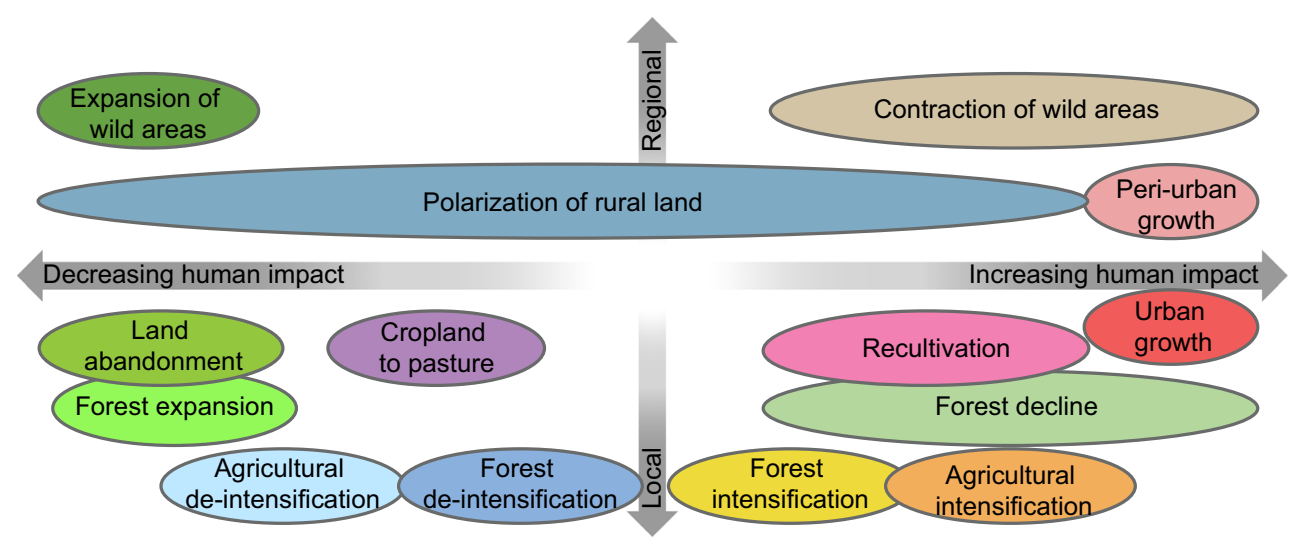

Fig. 2 Land change trajectories arranged according to the human impact on the landscape (horizontal axis) and the spatial range accounted for in their description (vertical axis)

sports, camping). In the mapping approach developed by van Berkel and Verburg (2011), suitability for nature-based tourism depends on landscape features such as relief, proximity to rivers, lakes and coasts, the presence of natural monuments, and high nature value farmland. This indicator was given as a dimensionless index. Data were provided by Tucker et al. (2013).

\section{Pollination}

Pollination is vital for flowering plants and is indispensable for agriculture. For a wide range of crops, bees and other insects are the most important biotic pollen vectors. Here, pollination was expressed as a flow and depended on assumptions on potential habitat (\% area) in the vicinity of croplands calculated according to the method documented by Serna-Chavez et al. (2014) and provided by Tucker et al. (2013).

\section{Maintenance of soil quality}

Soil organic matter stock in the topsoil is a common proxy for the capacity of the ecosystem to maintain soil quality (Reeves 1997). Soil organic matter $\left(\mathrm{Gg}\right.$ per $\left.\mathrm{km}^{2}\right)$ estimates for the reference year were derived from Jones et al. (2004) and Jones et al. (2005) and provided by Tucker et al. (2013).

\section{Flood regulation}

Flood regulation is the capacity of land to mitigate and lower flood events by means of runoff reduction through retention and evapotranspiration. Its supply depends on the land cover and land use, soil conditions, and location factors. Flood regulation is given as a dimensionless index following Stürck et al. (2014).
We characterized locations subject to land use change by the location characteristics in the reference year. We hypothesized that the locations affected by different land change trajectories differ in their location characteristics. We tested whether location characteristics differed significantly for the different land change trajectories within one scenario using a Mann-Whitney $U$ test. Significant differences indicated that different land change trajectories affected different locations. We subset particular trajectories (land abandonment to land abandonment only and expansion of wild areas, and polarization of rural land to land abandonment and intensification of cropland and pasture) and visualized location characteristics per land change trajectory across all land use scenarios using star plots. All analyses were conducted using R (R Development Core Team 2012).

\section{Results}

\section{Land change trajectories}

We quantified the occurrence of each land change trajectory per scenario (Fig. 5). To analyze the consistency of the occurrence of land change trajectories between scenarios, we overlaid particular land change trajectories in all scenarios and quantified their frequency of occurrence at each grid cell (Figs. 6, 7). We summarized hotspots of land change trajectories in Fig. 8. An overlay of particular land change trajectory hotspots in different scenarios is presented in Fig. 9. Overall, land change trajectories have largest extents in the "Libertarian Europe" (V-A1) and "Social Democracy Europe" (V-B1) scenarios. Grid cells which face change in all scenarios are particularly frequent in eastern Europe, while in western Europe, future changes are more diverse across scenarios and overlap less (Fig. 6). 


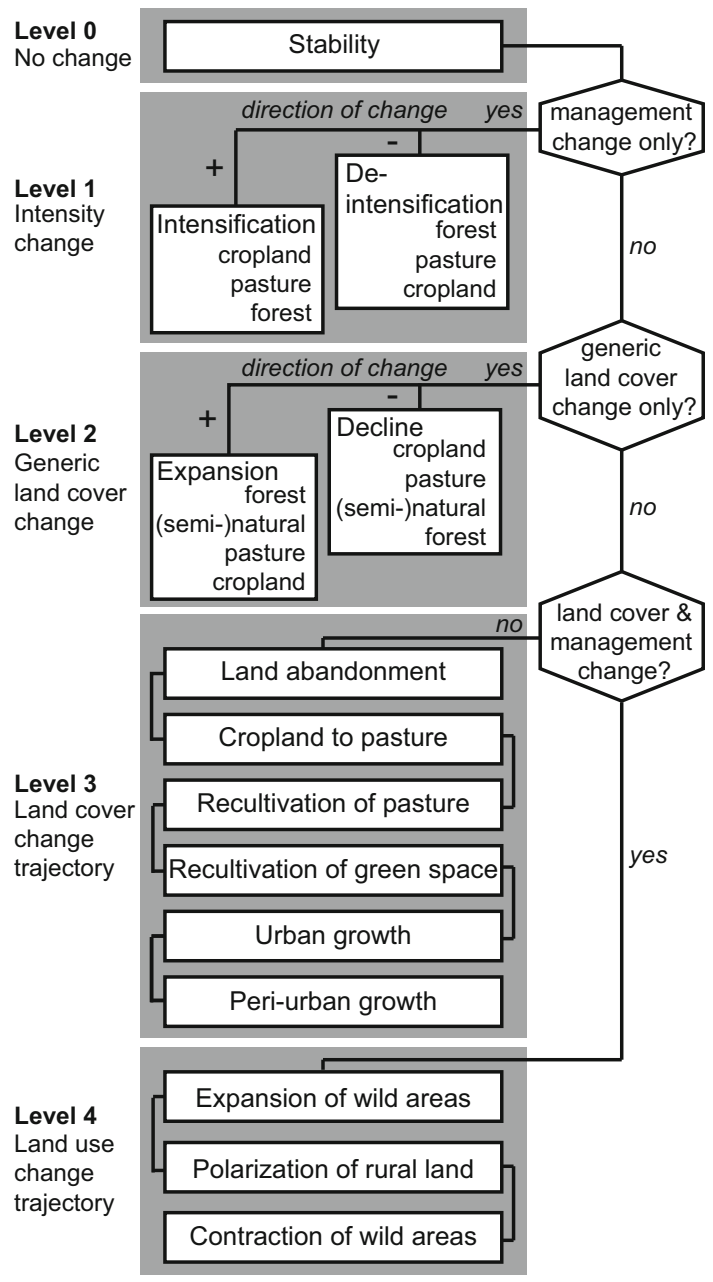

Fig. 3 Hierarchy of land change trajectories used in creation of land change hotspot maps

In the following section, we present characteristics of land change trajectories in the different land use scenarios.

In "Libertarian Europe" (V-A1), change affects particularly the agricultural sector. Land abandonment affects more than $170,000 \mathrm{~km}^{2}$ of agricultural land. This development is accompanied by conversion of cropland to pasture and large areas of de-intensification trajectories (Fig. 5). V-A1 displays the largest extent of expansion of wild areas. Intensification of agricultural land predominately occurs within areas characterized by polarization of rural land. On the other hand, large extents of green space are recultivated to agricultural land (ca. $41,000 \mathrm{~km}^{2}$ ).

Land abandonment hotspots are located particularly in eastern and southern Europe (Fig. 8). Agricultural landscapes in northern Italy, Poland, and Romania are affected by land abandonment in all scenarios (Fig. 9a), while hotspots in western Europe are more diverse between scenarios and most frequent under "Libertarian Europe" (V-A1) and "Social Democracy Europe" (V-B1). Land

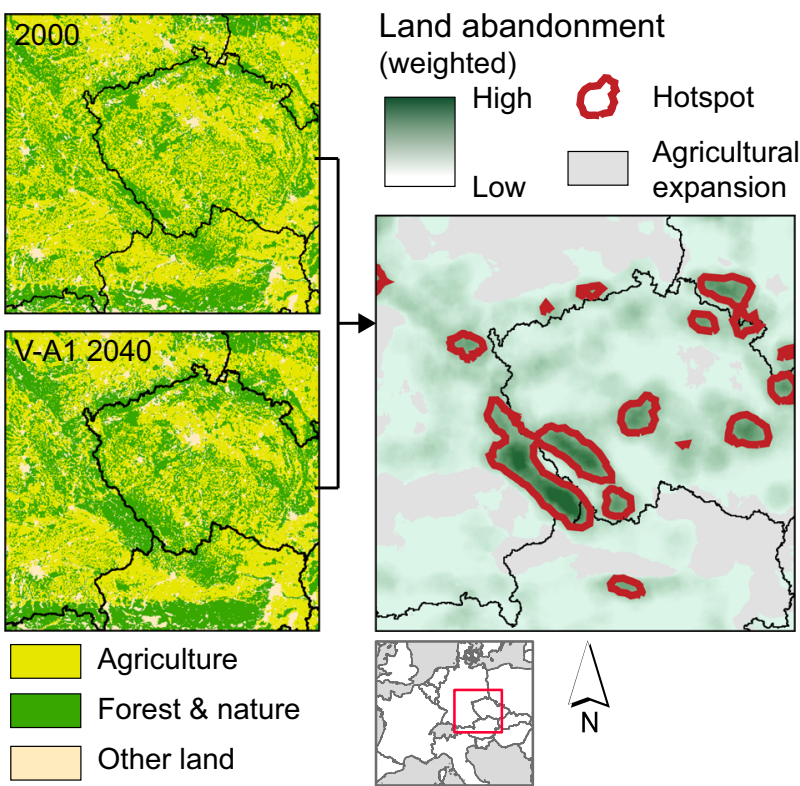

Fig. 4 Hotspot mapping approach, exemplified for the land change trajectory land abandonment

abandonment hotspots are often accompanied by expansion of wild areas, particularly in southern Europe. The conversion of cropland to pasture is a trajectory predominately found in Portugal, Spain, and the UK, and hotspots of deintensification trajectories dominate as well in Portugal, the UK, and France. Hotspots of polarization of rural land are mostly confined to Poland, Hungary, and Romania.

In "Eurosceptic Europe" (V-A2), the agricultural sector follows a different development. Agriculture intensifies the most as compared to the other scenarios (Fig. 5). Land abandonment is less frequent than in V-A1, yet is not offset by recultivation of green space, resulting in a relative loss of agricultural area also in V-A2. Expansion of wild areas is less frequent than in V-A1, and hotspots are confined mostly to Alpine regions and Scandinavia. Extents of contraction of wild areas, on the other hand, are comparable to V-A1 and offset by expansion of wild areas within the EU.

In "Social Democracy Europe" (V-B1), changes in the agricultural sector are similar to V-A1. While land abandonment is on a similar level $\left(173,000 \mathrm{~km}^{2}\right)$ and hotspots are situated in similar regions as in V-A1, expansion of wild areas is less abundant than in V-A1 and hotspots are less associated with land abandonment hotspots (Fig. 8). Also contraction of wild areas affects larger areas $\left(19,000 \mathrm{~km}^{2}\right)$ than in V-A1 and V-A2 and is associated with forest intensification, for example, in Sweden (Fig. 8). Polarization of rural land is most frequent under V-B1 and is the only one with hotspots of polarization outside of eastern Europe, for example in northern France.

Agricultural change trajectories in "European Localism" (V-B2) are comparable to V-A2, for example, in 


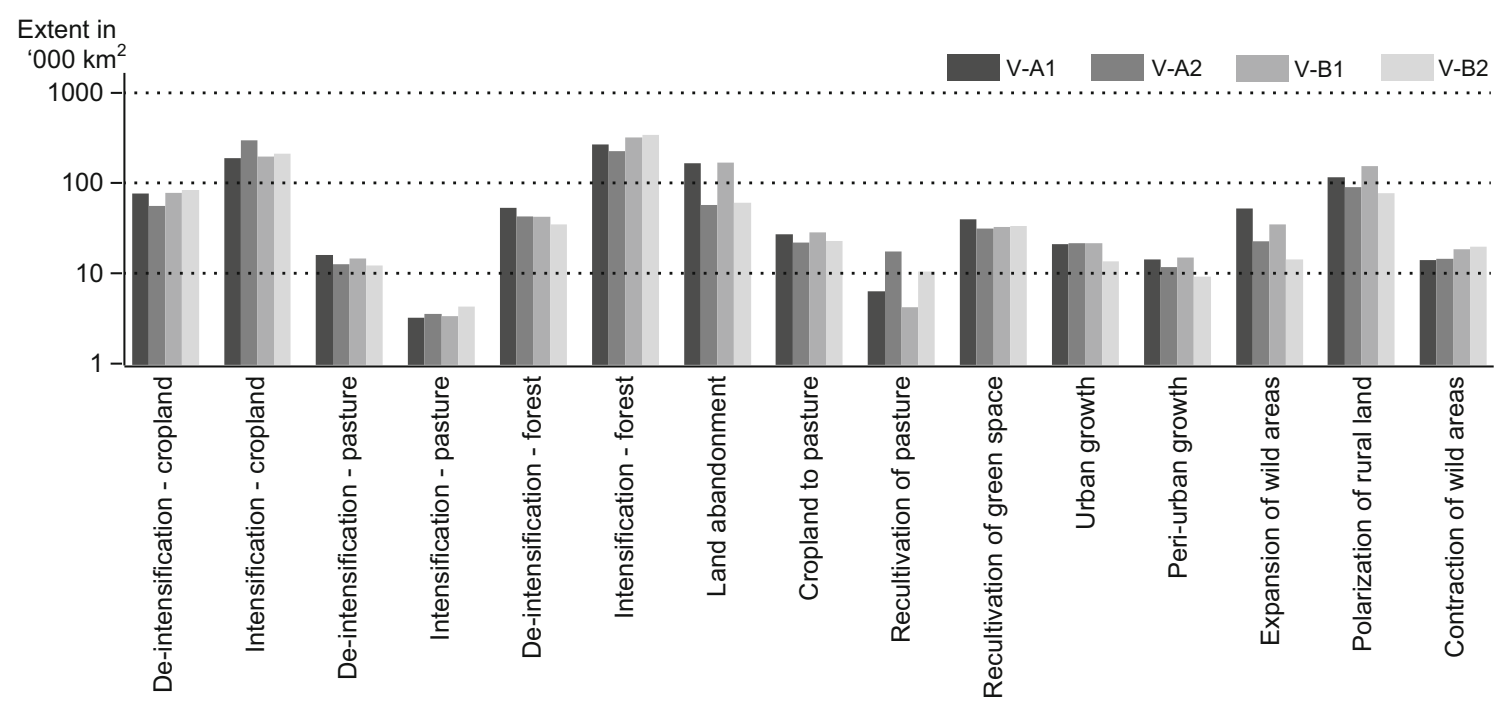

Fig. 5 Spatial occurrence of land change trajectories (in $1000 \mathrm{~km}^{2}$ ) per scenario

terms of land abandonment and recultivation of pasture. In $\mathrm{V}-\mathrm{B} 2$, the extent of expansion of wild areas is smallest across scenarios, with hotspots predominately located in Scandinavia and the Alps. V-B2 is the only scenario in which the trajectory contraction of wild areas covers larger extents than expansion of wild areas $(20,000$ and $15,000 \mathrm{~km}^{2}$, respectively). While urban growth is comparatively high in the other scenarios $\left(22,000 \mathrm{~km}^{2}\right)$, expansion of urban cores is smaller in V-B2 $\left(14,000 \mathrm{~km}^{2}\right)$.

Land change trajectories are affected differently by the underlying scenario storylines. While, for example, grid cells which are affected by contraction of wild areas overlap to great extents between scenarios (Fig. 7f), other trajectories are more versatile, for example expansion of wild areas (Fig. 7c). Trajectory hotspots, in general, display less variability. In Fig. 9, scenario hotspots of (a) land abandonment, (b) polarization of rural land, and (c) expansion of wild areas were overlaid. Hotspots of land abandonment are comparatively stable in eastern and southern Europe and more scenario-dependent in western Europe (Fig. 9a). Hotspots of polarization of rural land, on the other hand, overlap less frequently, but, except for one exception (V-B1), all hotspots are situated in eastern Europe (Fig. 9b). Expansion of wild areas is comparatively stable in the Alps, but more scenario-dependent in the rest of the EU (Fig. 9c).

\section{Location characteristics of land change trajectories in land use scenarios}

Land change trajectories can be differentiated based on the composition of location characteristics in the reference year. Most location characteristics associated with a particular

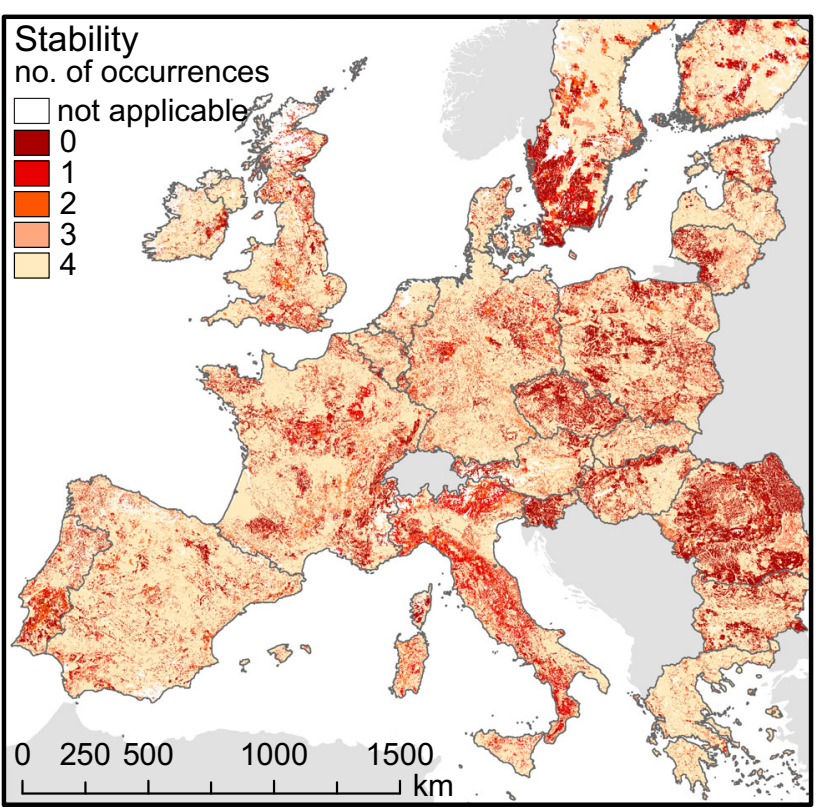

Fig. 6 Frequency of stability in the four scenarios

land change trajectory were similar across scenarios. Recultivation of pasture, cropland to pasture, and expansion of wild areas showed larger differences between scenarios (Fig. S7), particularly due to variations in carbon sequestration and erosion risk. Because of the similarity in location characteristics across scenarios, we exemplarily present the results for V-B1 here (Fig. 10). The results for the other scenarios are presented in Fig. S7 and Tables S3-S6.

Despite originating from similar land uses in the reference year, particular trajectories differ considerably in terms of their location characteristics, specifically with respect to carbon sequestration, pollination, maintenance of 

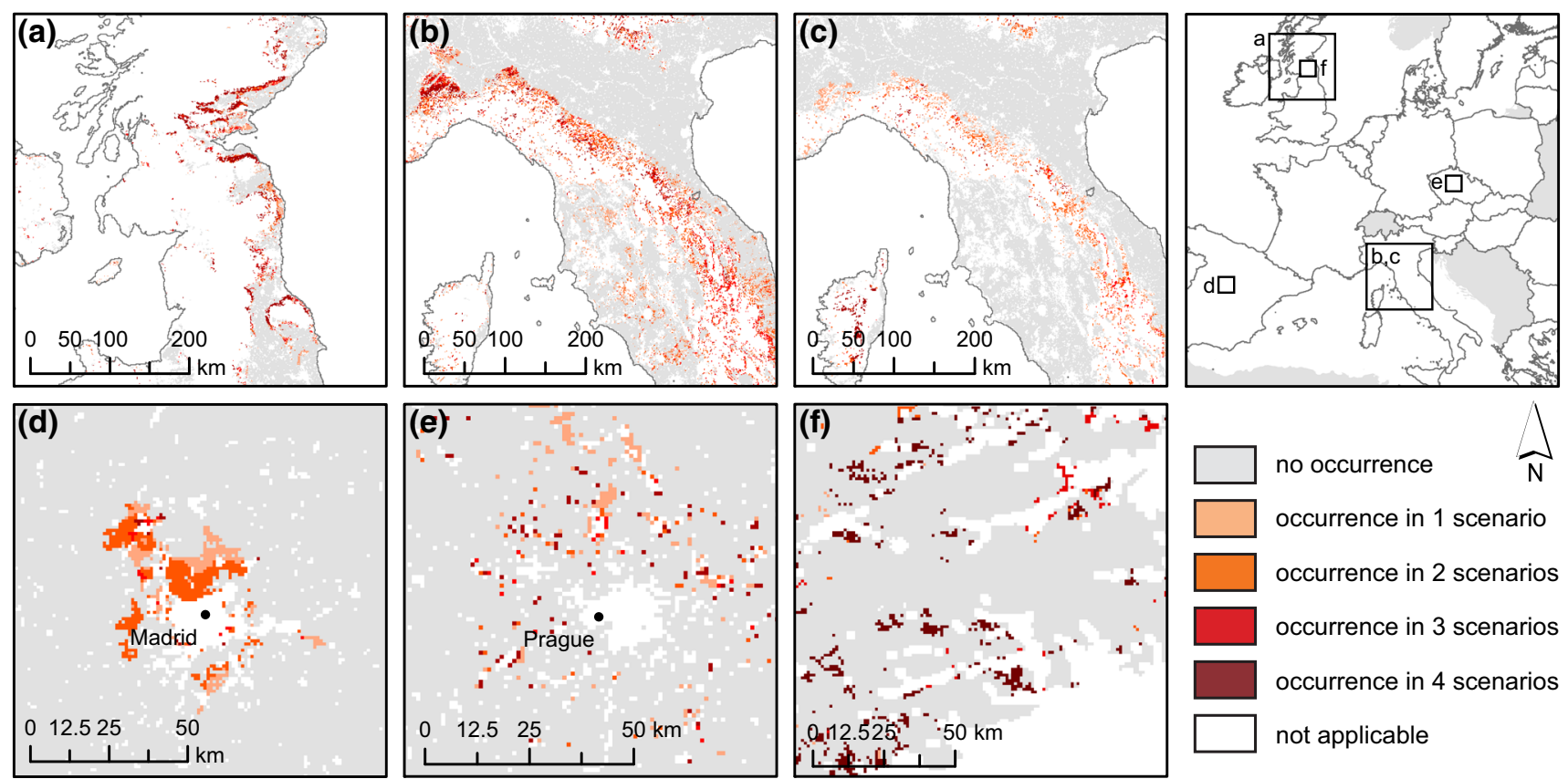

Fig. 7 Frequency of occurrence of land change trajectories in the four scenarios. a Cropland to pasture, $\mathbf{b}$ land abandonment, $\mathbf{c}$ expansion of wild areas, $\mathbf{d}$ urban growth, $\mathbf{e}$ peri-urban growth, $\mathbf{f}$ contraction of wild areas

soil quality, and flood regulation ( $p$ values $<0.05$, see Tables S7-S12). For example, location characteristics of intensifying forest grid cells differ from de-intensifying forest grid cells, cropland converted to pasture differs from cropland that intensifies toward 2040, and also the context of land abandonment (e.g., polarization of rural land, or expansion of wild areas) reveals significantly different location characteristics.

Locations characterized by intensification of forest management showed highest amounts of carbon sequestration, followed by locations subject to contraction of wild areas and recultivation of green space. In 2000, erosion risk was highest at locations affected by the trajectories cropland to pasture and land abandonment. Nature-based tourism was most pronounced at locations which faced either contraction or expansion of wild areas. Pollination was only quantified for cropland, and was highest for cropland facing conversion to pasture, and for cropland associated with polarization of rural land. Maintenance of soil quality was on average highest at locations of forest management intensification, or locations which faced either contraction or expansion of wild areas. Flood regulation was most dominant for the land change trajectory de-intensification of forest management, as well as pasture intensification and expansion of wild areas.

In general, the trajectories contraction of wild areas, expansion of wild areas, and intensification of forest management occurred at locations with the highest overall ecosystem service provision (Fig. 10 and Table S5).

\section{Discussion}

\section{Identification of land change trajectories}

We used a novel combination of models to address both intensity and area changes in multiple land use sectors and integrates these different dimensions of land use change by delineating typical land change trajectories. Based on a novel set of scenarios and a chain of simulation models that address both changes in land cover and land use intensity, we have provided an analysis of the spatial patterns of land use change that Europe may face in the coming decades. Rather than presenting the raw modeling results, we delineated and quantified typical land change trajectories of varying complexity while accounting for the regional context of land change that was often disregarded in previous studies (e.g., Navarro and Pereira 2012).

A strength of the approach is that the scenarios reflect the uncertainty in future developments of the driving factors of land use in Europe and show how these work out in on the mosaic of different land change trajectories across the EU territory. At the same time, the uncertainty in data and model structures is not represented in our results. Other studies have investigated the propagation of error and uncertainty in linked modeling systems as used in this study (Verburg et al. 2013; Dunford et al. 2014). The study of Verburg et al. (2013) indicates that although uncertainty is inherently large, robust spatial patterns of change are obtained. Unfortunately, the absence of sufficiently 

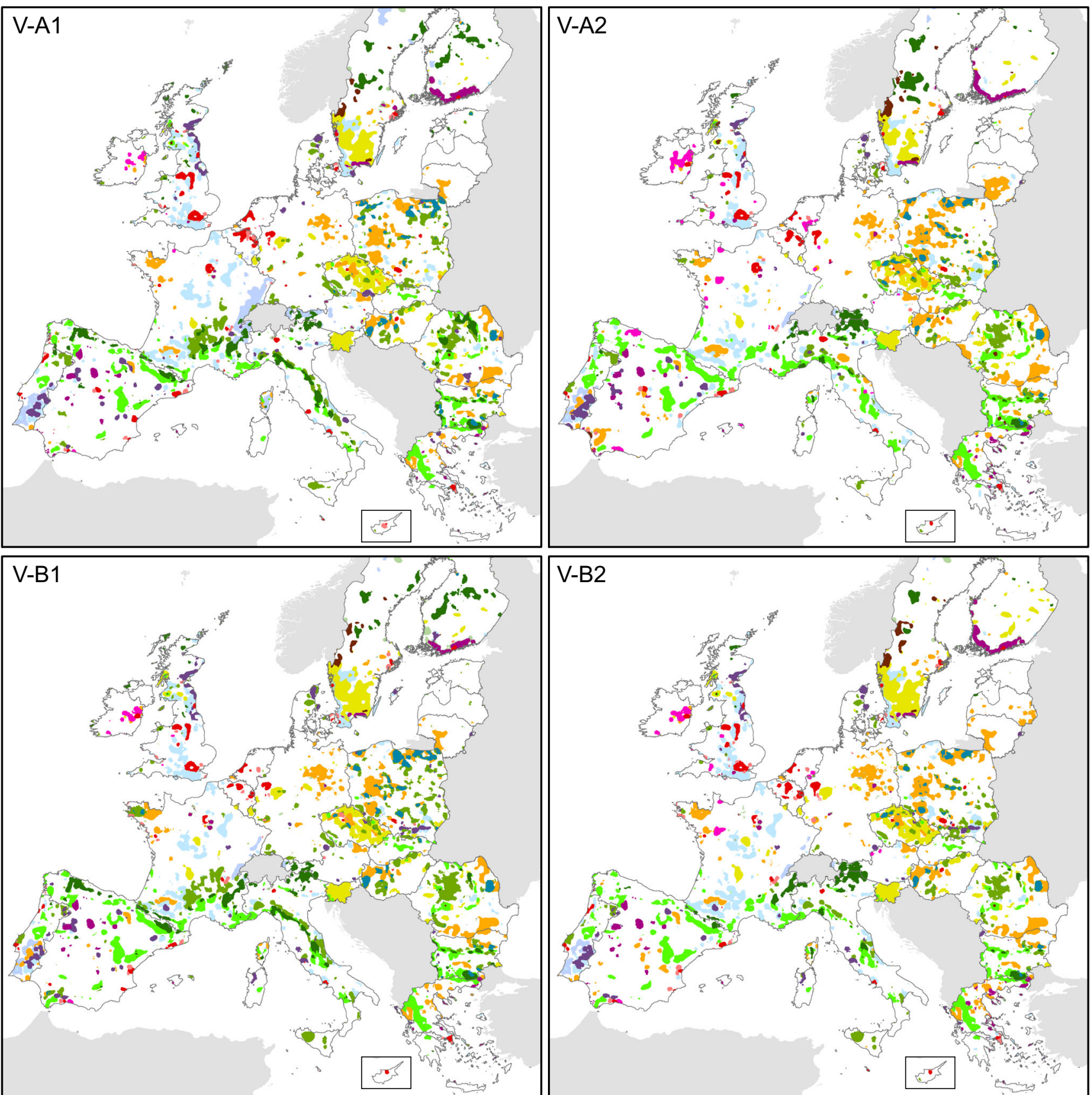

\section{Land change trajectories}

\section{Level 1 - Intensity change}

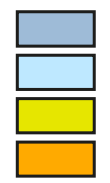

De-intensification - forest

De-intensification - cropland \& pasture

Intensification - forest

Intensification - cropland \& pasture

Level 2 - Generic land cover change

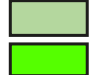

Forest decline

Forest expansion
Level 3 - Land cover change trajectory Level 4 - Land use change trajectory

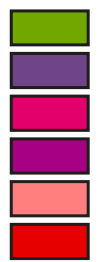

Land abandonment

Cropland to pasture

Recultivation of pasture

Expansion of wild areas

Polarization of rural land

Contraction of wild areas

Recultivation of green space

Peri-urban growth

Urban growth

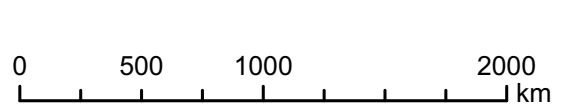

Fig. 8 Summary maps of land change trajectory hotspots per scenario 

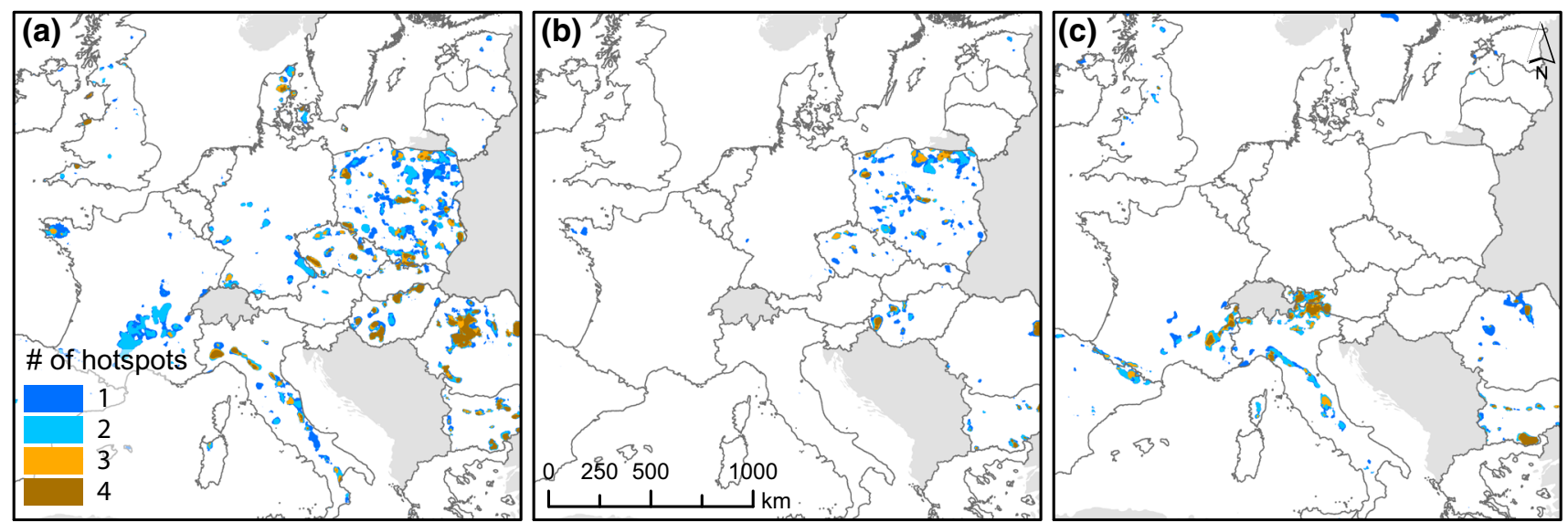

Fig. 9 Hotspot overlaps across the four scenarios for land change trajectories, a land abandonment, $\mathbf{b}$ polarization of rural land, and $\mathbf{c}$ expansion of wild areas

consistent change data for the European scale across longer time periods makes the validation of broad-scale land use models impossible.

The choice of land change trajectories in our study was largely determined by the information available from the underlying simulation models. This resulted in the trajectories to predominately reflect anthropogenic land use change in human-dominated landscapes such as agricultural, seminatural, or forest lands, while trajectories where the models did not provide sufficient information were not represented, for example glacier loss, or the conversion of wet- and peatlands. The approach contains the risk of oversimplification of complex land change trajectories. For example, the contribution of land abandonment to expansion of wild areas can be counteracted by the construction of roads that fragment large natural areas and impact the diversity and abundance of (native) species (Fahrig 2003). Yet, we ignored fragmentation through infrastructure development, as infrastructure expansion was not represented in the models. Other limitations of the approach relate to the sometimes arbitrary rules for defining the land change trajectories and the categorical inputs maps (e.g., management intensity levels). Moreover, while our analysis captures change within a particular region, some land change trajectories may have impacts elsewhere. For example, land abandonment can link to agricultural expansion in remote places (Fischer et al. 2014), which we are not able to trace with our approach.

Our hotspot maps help to visually access multiple complex change processes in one map and allow quantifying the consistency of severe changes across regions and scenarios. The hotspot maps contextualize grid level change within conditions and processes within their neighborhood. Assumptions on the considered neighborhood extent and thresholds to define a hotspot affect the delineation. However, there are no ecological processes that can be relied on to define a particular scale for consideration of a neighborhood. The neighborhood is chosen to be able to distinguish regional patterns by simultaneously reducing boundary effects common in analyses at the scale of administrative units or environmental zones. To test the sensitivity of the chosen approach, we recalculated the trajectory polarization of rural land for the V-B1 scenario with variable moving window sizes between $5 \mathrm{~km}$ and $50 \mathrm{~km}$ and quantified the consistency of the resulting hotspots by the degree of overlap (Fig. S2). Seventy-nine percentage of hotspot area based on a $5-\mathrm{km}$ moving window lied within hotspots based on a $15-\mathrm{km}$ moving window, and $84 \%$ of hotspot area based on a $15-\mathrm{km}$ moving window lied within hotspots based on a 50-km moving window, indicating a good agreement across scales and limited sensitivity to the chosen neighborhood size.

Hotspot definitions in the literature are ambiguous, and arbitrarily chosen cutoff values such as the $10 \%$ quantile are commonly used for visualization or prioritization (e.g., Eigenbrod et al. 2010; Bai et al. 2011; Wu et al. 2013). The ambiguity of hotspot definitions necessitates clear documentation of the chosen hotspot delineation.

\section{Analysis of land change trajectories and land change hotspots in Europe}

Opposing trends in agricultural productivity across Europe were suggested by Audsley et al. (2006) as a result of climate change. Suitability for agriculture increases in northern Europe and decreases in the south. This process is reflected in our results: Recultivation is frequent in southern Finland and Sweden, while land abandonment is more widespread in Portugal and Italy. Particularly "Libertarian Europe" (V-A1) constitutes large changes in the agricultural sector: Liberalization of trade implies a strong 

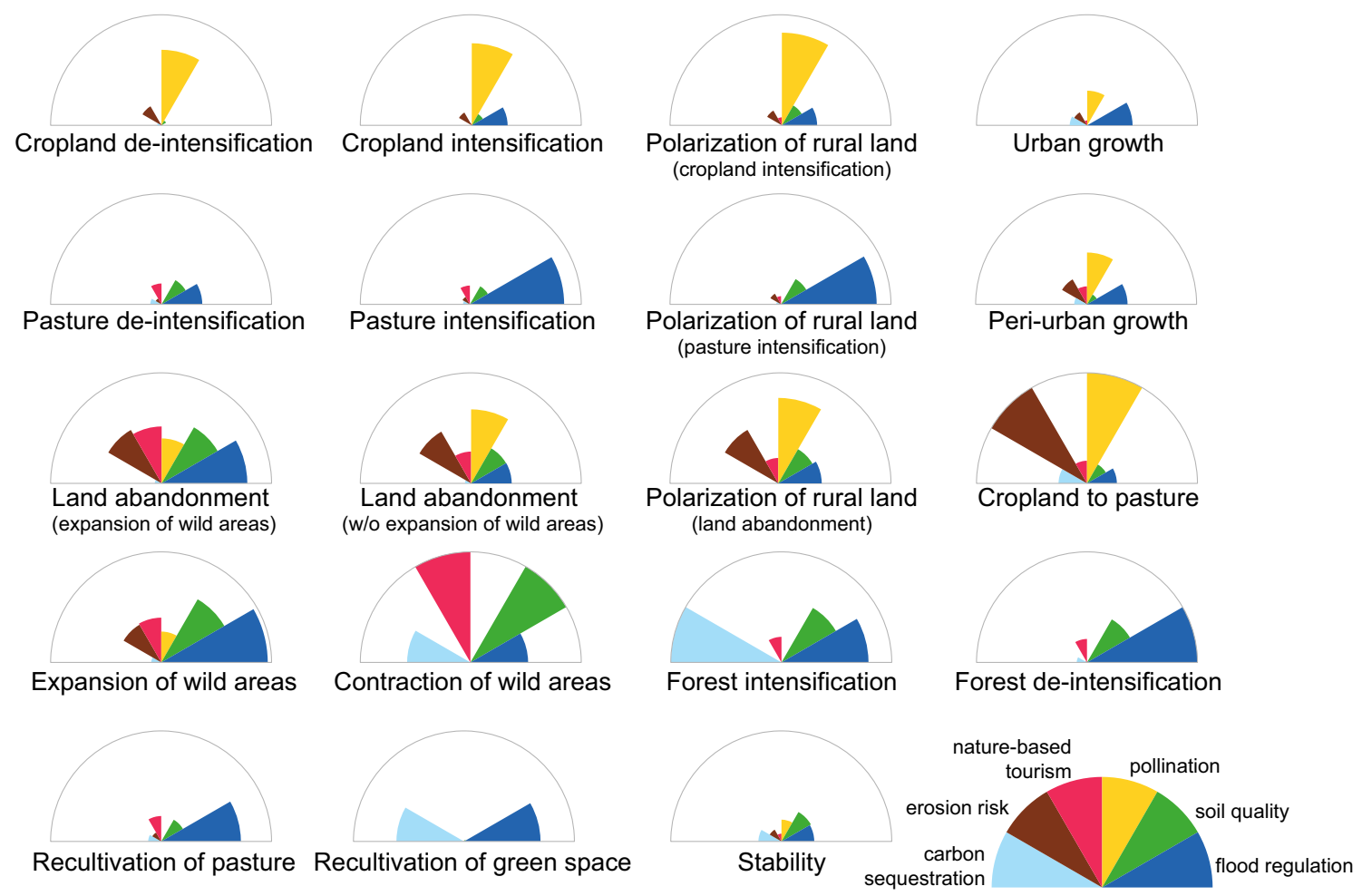

Fig. 10 Location characteristics associated with land change trajectories in scenario V-B1

orientation toward global markets and cuts of subsidies for European farmers. This development favors large-scale land abandonment, particularly in southern Europe. Land abandonment can have mixed outcomes. On the one hand, land abandonment can contribute to ecological restoration and increased carbon storage (Grau et al. 2004). On the other hand, land abandonment can result in reduced water availability (Rey Benayas 2007), higher wildfire risk (Moreira and Russo 2007), soil erosion (Stanchi et al. 2012), or the loss of agro-biodiversity and cultural landscapes (DLG 2005; Stoate et al. 2009; Fischer et al. 2012). Landscapes which face land abandonment and contraction of wild areas often feature high scenic and cultural heritage values. Changes in these landscapes can reduce the tourism and recreation functions leading to economic losses in local communities. Expansion of wild areas could therefore be a chance to maintain landscapes attractive for tourism and recreation.

All scenarios indicate that agricultural intensification and land abandonment frequently emerge within the same region in the form of polarization of rural land. Polarization of rural land is particularly frequent in "Social Democracy Europe" (V-B1) and most pronounced in eastern Europe (Figs. 5, 9b). These developments indicate substantial changes, socioeconomically and environmentally, for the affected regions (MacDonald et al. 2000; Cramer et al. 2008). The relationship between increasing agricultural productivity and declining agricultural areas resulting from abolished agricultural policy regulations is well in line with previous work (Rounsevell et al. 2006; Verburg et al. 2008; Renwick et al. 2013). However, the regional diversity in land change trajectories originating from these processes was not addressed previously.

The ecological footprint of European consumption outside of Europe is projected to increase drastically in V-A1, due to very little efforts to control land use change driven by agricultural expansion, but particularly due to increased food and feed demand compared to the reference year. Pasture extent in the EU, however, declines under all storylines, and modeled decreases in grazing intensity correspond well with other modeling studies as reviewed in Busch (2006), where these trends are explained by changes in animal feed (i.e., fodder crops instead of grazing) and shifts in meat preference (i.e., from beef to pork and poultry). Thus, land abandonment may lead to increased displacement of agricultural production to regions outside Europe, such as southeast Asia and South America (Meyfroidt et al. 2010; Kastner et al. 2011), which entails strong environmental trade-offs. Recultivation of abandoned farmland in the temperate zone has been suggested as an option to increase agricultural production within Europe, while mitigating some of the unwanted outcomes of land abandonment (Koning et al. 2008; Siebert et al. 2010; Johnston et al. 2011). 
In "Eurosceptic Europe" (V-A2), a main policy theme impacting on the agricultural sector is European protectionism. Agricultural subsidies prevail, and trade regulations are installed (as opposed to V-A1 and V-B1). As a result, intensification of agriculture is high, and de-intensification processes are limited (as opposed to V-A1, where it is a European-wide trajectory). Expansion of wild areas is less frequent compared to V-A1 and V-B1. As a combined result of intensifying agricultural systems and weak regulation of land use change, wild areas contract (mostly in Finland, France, Greece, and Spain), and natural ecosystems are under strong pressure in this scenario. Contraction of wild areas, recultivation of green space, and intensification of forest management pose the largest threats for regulating and supporting services, such as carbon sequestration and maintenance of soil quality, under all storylines, as locations which face these land change trajectories feature currently highest ecosystem service provisioning.

In "European Localism" (V-B2), in contrast, de-intensification of agriculture is most frequent across scenarios, and intensification affects less agricultural area than in V-A2. In $\mathrm{V}-\mathrm{B} 2$, agricultural area in the EU remains closest to the reference year. Accordingly, and despite stricter land use regulations compared to V-A2, expansion of wild areas is least frequent, and contraction of wild areas is not compensated for.

Forest cover increases considerably across all scenarios (2.9-3.7\% of total EU area), which is in line with observed reforestation trends over the last decades (Zanchi et al. 2007) and projections in previous scenario studies (Schröter et al. 2005; Rounsevell et al. 2006). Intensification of forest management is most frequent in Scandinavia and mountainous areas across Europe, even in the scenario projecting least intensification (V-A2). Regional declines of forest and seminatural land, but particularly intensification of forest management leads to the contraction of wild areas, particularly in Scotland and Scandinavia. Contracting wild areas overlap more among scenarios than locations subject to expansion of wild areas, which suggests a higher path dependency for this trajectory.

Despite a similar strong population growth, increases in the extent of built-up area are $3 \%$ smaller in V-A2 as compared to V-A1 as a result of less economic growth. However, at the same time, urban areas grow stronger in $\mathrm{V}-\mathrm{A} 2$ than in V-A1, while peri-urban growth is much less pronounced. This reflects an emphasis of compact urban growth in V-A2 as opposed to urban sprawl in V-A1 (Fig. 5).

\section{Conclusions}

The identification and visualization of land change trajectories provide a number of important insights into future land use in Europe. Some land change trajectories, particularly those related to land abandonment and agricultural intensification, are very variable across scenarios, due to different storylines with respect to agricultural subsidies and trade. At the same time, many hotspots of land change are found at similar locations across the scenarios, showing much less variation across scenarios as compared to the full spatial extent of the trajectories. This indicates a high likelihood for those regions, largely irrespective of future developments, to experience a particular type of land change. It also suggests that the largescale policies and regulations assumed under the more regulated scenarios do not sufficiently counteract these anticipated changes. Therefore, these regions may require local adaptation strategies to deal with the land change pressures and opportunities in the next decades. The differences in the response of particular land change trajectories to scenario conditions thus require different policy and planning tools in order to steer them in desired directions. Likewise, a high spatial variation of different, sometimes contrasting, land change trajectories across the EU also reflects differences in the socioeconomic, environmental, and land use history across Europe.

Location characteristics are changing in the course of land change, which involves the risk of losing pivotal ecosystem services. We highlighted that locations affected by certain land change trajectories can be portrayed by a range of distinctive location characteristics such as ecosystem service provision in the reference year. Our results can support the discussion on replacement costs for ecosystem services (e.g., Winfree et al. 2011) and address how ecosystem service loss can be compensated for (e.g., Gardner et al. 2013; van Teeffelen et al. 2014). Our findings indicate the need for region-specific planning and policy making to guide land change to avoid negative impacts on environment and society.

Acknowledgments The work conducted in this paper was financed by the European Comission-FP7 Projects VOLANTE (No. 265104), OPERAs (No. 308393), and HERCULES (No. 603447). TK gratefully acknowledges funding by the Einstein Foundation Berlin.

Open Access This article is distributed under the terms of the Creative Commons Attribution 4.0 International License (http://creative commons.org/licenses/by/4.0/), which permits unrestricted use, distribution, and reproduction in any medium, provided you give appropriate credit to the original author(s) and the source, provide a link to the Creative Commons license, and indicate if changes were made.

\section{References}

Alexandratos N, Bruinsma J (2012) World agriculture towards 2030/2050: the 2012 revision. ESA Working paper No. 12-03. Rome, FAO

Audsley E, Pearn KR, Simota C, Cojocaru G, Koutsidou E, Rounsevell MDA, Trnka M, Alexandrov V (2006) What can scenario modelling tell us about future European scale 
agricultural land use, and what not? Environ Sci Policy 9:148-162. doi:10.1016/j.envsci.2005.11.008

Bai Y, Zhuang C, Ouyang Z, Zheng H, Jiang B (2011) Spatial characteristics between biodiversity and ecosystem services in a human-dominated watershed. Ecol Complex 8:177-183. doi:10. 1016/j.ecocom.2011.01.007

Britz W, Witzke P (2012) CAPRI model documentation 2012. University Bonn, Bonn

Brown DG, Verburg PH, Pontius RG, Lange MD (2013) Opportunities to improve impact, integration, and evaluation of land change models. Curr Opin Environ Sustain 5:452-457. doi:10. 1016/j.cosust.2013.07.012

Brus DJ, Hengeveld GM, Walvoort DJJ, Goedhart PW, Heidema AH, Nabuurs GJ, Gunia K (2011) Statistical mapping of tree species over Europe. Eur J For Res 131:145-157. doi:10.1007/s10342011-0513-5

Busch G (2006) Future European agricultural landscapes-What can we learn from existing quantitative land use scenario studies? Agric Ecosyst Environ 114:121-140. doi:10.1016/j.agee.2005. 11.007

Cramer VA, Hobbs RJ, Standish RJ (2008) What's new about old fields? Land abandonment and ecosystem assembly. Trends Ecol Evol 23:104-112. doi:10.1016/j.tree.2007.10.005

DeFries RS, Foley JA, Asner GP (2004) Land-use choices: balancing human needs and ecosystem function. Front Ecol Environ 2:249-257.

doi:10.1890/15409295(2004)002[0249:LCBHNA]2.0.CO;2

DLG (2005) Land abandonment, biodiversity, and the CAP. Land abandonment and biodiversity in relation to the 1st and 2nd pillars of the EU's Common Agricultural Policy; Outcome of an international seminar in Sigulda, Latvia, 7-8 October 2004 Government Service for Land and Water Management of The Netherlands (DLG), Utrecht The Netherlands

Dunford R, Harrison PA, Jäger J, Rounsevell MDA, Tinch R (2014) Exploring climate change vulnerability across sectors and scenarios using indicators of impacts and coping capacity. Clim Change. doi:10.1007/s10584-014-1162-8

Eigenbrod F, Armsworth PR, Anderson BJ, Heinemeyer A, Gillings S, Roy DB, Thomas CD, Gaston KJ (2010) The impact of proxybased methods on mapping the distribution of ecosystem services. J Appl Ecol 47:377-385. doi:10.1111/j.1365-2664. 2010.01777.x

Elbersen B, Staritsky I, Hengeveld G, Schelhaas MJ, Naeff H, Böttcher H (2012) Atlas of EU biomass potentials. Deliverable 3.3: spatially detailed and quantified overview of EU biomass potential taking into account the main criteria determining biomass availability from different sources. http://ec.europa.eu/ energy/intelligent/projects/sites/iee-projects/files/projects/docu ments/biomass_futures_atlas_of_technical_and_economic_bio mass_potential_en.pdf. Accessed 10 Oct 2014

Erb K-H, Haberl H, Jepsen MR, Kuemmerle T, Lindner M, Müller D, Verburg PH, Reenberg A (2013) A conceptual framework for analysing and measuring land-use intensity. Curr Opin Environ Sustain 5:464-470. doi:10.1016/j.cosust.2013.07.010

Eurostat (2001) Degree of urbanisation. http://epp.eurostat.ec.europa. eu/portal/page/portal/gisco_Geographical_information_maps/ popups/references/population_distribution_demography. Accessed 5 April 2014

Fahrig L (2003) Effects of habitat fragmentation on biodiversity. Annu Rev Ecol Evol Syst 34:487-515. doi:10.1146/annurev. ecolsys.34.011802.132419

Fischer J, Hartel T, Kuemmerle T (2012) Conservation policy in traditional farming landscapes. Conserv Lett 5:167-175. doi:10. 1111/j.1755-263X.2012.00227.x

Fischer J, Abson DJ, Butsic V, Chappell MJ, Ekroos J, Hanspach J, Kuemmerle T, Smith HG, von Wehrden H (2014) Land sparing versus land sharing: moving forward. Conserv Lett 7:149-157. doi:10.1111/conl.12084

Fürst C, Helming K, Lorz C, Müller F, Verburg PH (2013) Integrated land use and regional resource management-a cross-disciplinary dialogue on future perspectives for a sustainable development of regional resources. J Environ Manage 127:S1S5. doi:10.1016/j.jenvman.2012.12.015

Gardner TA, von Hase A, Brownlie S, Ekstrom JMM, Pilgrim JD, Savy CE, Stephens RTT, Treweek J, Ussher GT, Ward G et al (2013) Biodiversity offsets and the challenge of achieving no net loss. Conserv Biol 27:1254-1264. doi:10.1111/cobi.12118

Geist H, McConnell W, Lambin E, Moran E, Alves D, Rudel T (2006) Causes and Trajectories of land-use/cover change. In: Lambin E, Geist $\mathrm{H}$ (eds) Land-use and land-cover change. Local Processes and Global Impacts. Springer, Berlin, pp 41-70

Grau HR, Aide TM, Zimmerman JK, Thomlinson JR (2004) Trends and scenarios of the carbon budget in postagricultural Puerto Rico (1936-2060). Glob Change Biol 10:1163-1179. doi:10. 1111/j.1529-8817.2003.00792.x

Johnston M, Licker R, Foley J, Holloway T, Mueller ND, Barford C, Kucharik C (2011) Closing the gap: global potential for increasing biofuel production through agricultural intensification. Environ Res Lett 6:034028. doi:10.1088/1748-9326/6/3/034028

Jones RJA, Hiederer R, Rusco R, Loveland PJ, Montanarella L (2004) The map of organic carbon in topsoils in Europe, Version 1.2, September 2003: explanation of special publication Ispra 2004 No. 72 (S.P.I.04.72). European Soil Bureau Research Report No. 17, EUR 21209 EN, p. 26 and 1 map in ISO B1 format. Office for Official Publications of the European Communities, Luxembourg

Jones RJA, Hiederer R, Rusco E, Montanarella L (2005) Estimating organic carbon in the soils of Europe for policy support. Eur J Soil Sci 56:655-671. doi:10.1111/j.1365-2389.2005.00728.x

Kallio AMI, Moiseyev A, Solberg B (2004) The global forest sector model EFI-GTM-The model structure. Internal Report No. 15. European Forest Institute, Joensuu, Finland

Kastner T, Erb K-H, Nonhebel S (2011) International wood trade and forest change: a global analysis. Glob Environ Change 21:947-956. doi:10.1016/j.gloenvcha.2011.05.003

Koning NBJ, van Ittersum MK, Becx GA, van Boekel MAJS, Brandenburg WA, van den Broek JA, Goudriaan J, van Hofwegen G, Jongeneel RA, Schiere JB et al (2008) Long-term global availability of food: continued abundance or new scarcity? NJAS Wagening J Life Sci 55:229-292. doi:10.1016/ S1573-5214(08)80001-2

Kuemmerle T, Erb K, Meyfroidt P, Müller D, Verburg PH, Estel S, Haberl H, Hostert P, Jepsen MR, Kastner T et al (2013) Challenges and opportunities in mapping land use intensity globally. Curr Opin Environ Sustain 5:484-493. doi:10.1016/j. cosust.2013.06.002

Lambin EF, Meyfroidt P (2011) Global land use change, economic globalization, and the looming land scarcity. Proc Natl Acad Sci USA 108:3465-3472. doi:10.1073/pnas.1100480108

Lotze-Campen H, Verburg PH, Popp A, Lindner M, Verkerk PJ, Moiseyev A, Schrammeijer E, Helming J, Tabeau A, Schulp CJE, van der Zanden EH, Lavalle C, Batista e Silva F, Walz A, Bodirsky BL Description of the linked modelling system of sector models and multi-sector assessments. (in preparation for this issue)

Lotze-Campen H, Müller C, Bondeau A, Rost S, Popp A, Lucht W (2008) Global food demand, productivity growth, and the scarcity of land and water resources: a spatially explicit mathematical programming approach. Agric Econ 39:325-338. doi:10.1111/j.1574-0862.2008.00336.x

Lotze-Campen H, Popp A, Beringer T, Müller C, Bondeau A, Rost S, Lucht W (2010) Scenarios of global bioenergy production: the 
trade-offs between agricultural expansion, intensification and trade. Ecol Modell 221:2188-2196. doi:10.1016/j.ecolmodel. 2009.10.002

Lotze-Campen H, Popp A, Verburg P, Lindner M, Verkerk H, Kakkonen E, Schrammeijer E, Schulp N, van der Zanden E, van Meijl H, Tabeau A, Helming J, Kuemmerle T, Lavalle C, Batista e Silva F, Eitelberg D (2014) Visions of land use transitions in Europe. Deliverable No: 7.3. Description of the translation of sector specific land cover and land management information. http://www.volante-project.eu/images/stories/DELIVER ABLES/VOLANTE_D7.3_Description_of_the_translation_of_ sector_specific_land_cover_and_management_information.pdf. Accessed 2 April 2015

Luderer G, Leimbach M, Bauer N, Kriegler E, Aboumahboub T, Curras TA, Baumstark L, Bertram C, Giannousakis A, Hilaire J, et al. (2013) Description of the REMIND model (Version 1.5). Potsdam, Germany

Luyssaert S, Jammet M, Stoy PC, Estel S, Pongratz J, Ceschia E, Churkina G, Don A, Erb K-H, Ferlicoq M et al (2014) Land management and land-cover change have impacts of similar magnitude on surface temperature. Nat Clim Chang 4:389-393. doi:10.1038/nclimate2196

MacDonald D, Crabtree JR, Wiesinger G, Dax T, Stamou N, Fleury P, Gutierrez Lazpita J, Gibon A (2000) Agricultural abandonment in mountain areas of Europe: environmental consequences and policy response. J Environ Manage 59:47-69. doi:10.1006/jema. 1999.0335

Mas J-F, Kolb M, Paegelow M, Camacho Olmedo MT, Houet T (2014) Inductive pattern-based land use/cover change models: a comparison of four software packages. Environ Model Softw 51:94-111. doi:10.1016/j.envsoft.2013.09.010

Matson PA, Vitousek PM (2006) Agricultural intensification: will land spared from farming be land spared for nature? Conserv Biol 20:709-710. doi:10.1111/j.1523-1739.2006.00442.x

Meyfroidt P, Rudel TK, Lambin EF (2010) Forest transitions, trade, and the global displacement of land use. Proc Natl Acad Sci USA 107:20917-20922. doi:10.1073/pnas.1014773107

Millenium Ecosystem Assessment (2005) Ecosystems and human well-being: synthesis. Island Press, Washington, DC

Moreira F, Russo D (2007) Modelling the impact of agricultural abandonment and wildfires on vertebrate diversity in Mediterranean Europe. Landsc Ecol 22:1461-1476. doi:10.1007/s10980007-9125-3

Nakicenovic N, Alcamo J, Davis G, de Vries B, Fenhann J, Gaffin S, Gregory K, Grübler A, Jung TY, Kram T, et al. (2000) Special report on emissions scenarios. A special report of working group III of the intergovernmental panel on climate change. Cambridge University Press, Cambridge

Navarro LM, Pereira HM (2012) Rewilding Abandoned Landscapes in Europe. Ecosystems 15:900-912. doi:10.1007/s10021-0129558-7

Neumann K, Elbersen B, Verburg P, Staritsky I, Pérez-Soba M, de Vries W, Rienks W (2009) Modelling the spatial distribution of livestock in Europe. Landsc Ecol 24:1207-1222. doi:10.1007/ s10980-009-9357-5

Overmars KP, Schulp CJE, Alkemade R, Verburg PH, Temme AJAM, Omtzigt N, Schaminée JHJ (2014) Developing a methodology for a species-based and spatially explicit indicator for biodiversity on agricultural land in the EU. Ecol Indic 37:186-198. doi:10.1016/j.ecolind.2012.11.006

Pérez-Soba M, Verburg PH, Koomen E, Hilferink MHA, Benito P, Lesschen JP, Banse M, Woltjer G, Eickhout B, Prins AG, et al. (2010) Land use modelling-implementation. Preserving and enhancing the environmental benefits of "land-use services". Report to the European Commission DG Environment under contract No.07.0307/2008/511790/SER/G1. Wageningen, The Netherlands

Plieninger T, van der Horst D, Schleyer C, Bieling C (2014) Sustaining ecosystem services in cultural landscapes. Ecol Soc 19:59. doi:10.5751/ES-06159-190259

R Development Core Team (2012) R: a language and environment for statistical computing. Version 3.1.1. R Foundation for Statistical Computing, Vienna, Austria

Ramankutty N, Foley JA (1999) Estimating historical changes in global land cover: croplands from 1700 to 1992. Glob Biogeochem Cycles 13:997-1027. doi:10.1029/1999GB900046

Reeves DW (1997) The role of soil organic matter in maintaining soil quality in continuous cropping systems. Soil Tillage Res 43:131-167. doi:10.1016/S0167-1987(97)00038-X

Renwick A, Jansson T, Verburg PH, Revoredo-Giha C, Britz W, Gocht A, McCracken D (2013) Policy reform and agricultural land abandonment in the EU. Land Use Policy 30:446-457. doi:10.1016/j.landusepol.2012.04.005

Rey Benayas J (2007) Abandonment of agricultural land: an overview of drivers and consequences. CAB Rev Perspect Agric Vet Sci Nutr Nat Resour. doi:10.1079/PAVSNNR20072057

Rounsevell MDA, Reginster I, Araújo MB, Carter TR, Dendoncker N, Ewert F, House JI, Kankaanpää S, Leemans R, Metzger MJ et al (2006) A coherent set of future land use change scenarios for Europe. Agric Ecosyst Environ 114:57-68. doi:10.1016/j.agee. 2005.11.027

Rounsevell MDA, Pedroli B, Erb K-H, Gramberger M, Busck AG, Haberl H, Kristensen S, Kuemmerle T, Lavorel S, Lindner M et al (2012) Challenges for land system science. Land Use Policy 29:899-910. doi:10.1016/j.landusepol.2012.01.007

Sallnäs O (1990) A matrix growth model of the Swedish forest. Studia forestalia Suecica, No. 183. Swedish University of Agricultural Sciences, Faculty of Forestry, Uppsala, Sweden

Schall P, Ammer C (2013) How to quantify forest management intensity in Central European forests. Eur $\mathrm{J}$ For Res 132:379-396. doi:10.1007/s10342-013-0681-6

Schelhaas MJ, Eggers J, Lindner M, Nabuurs GJ, Pussinen A, Päivinen R, Schuck A, Verkerk PJ, Werf van der DC, Zudin S (2007) Model documentation for the European Forest Information Scenario model (EFISCEN 3.1.3). Wageningen, The Netherlands, Alterra, Alterra-rapport 1559/Joensuu, Finland, EFI Technical Report 26

Schröter D, Cramer W, Leemans R, Prentice IC, Araújo MB, Arnell NW, Bondeau A, Bugmann H, Carter TR, Gracia CA et al (2005) Ecosystem service supply and vulnerability to global change in Europe. Science 310:1333-1337. doi:10.1126/science.1115233

Schulp CJE, Nabuurs GJ, Verburg PH, de Waal RH (2008) Effect of tree species on carbon stocks in forest floor and mineral soil and implications for soil carbon inventories. For Ecol Manage 256:482-490. doi:10.1016/j.foreco.2008.05.007

Seppelt R, Lautenbach S, Volk M (2013) Identifying trade-offs between ecosystem services, land use, and biodiversity: a plea for combining scenario analysis and optimization on different spatial scales. Curr Opin Environ Sustain 5:458-463. doi:10. 1016/j.cosust.2013.05.002

Serna-Chavez HM, Schulp CJE, van Bodegom PM, Bouten W, Verburg PH, Davidson MD (2014) A quantitative framework for assessing spatial flows of ecosystem services. Ecol Indic 39:24-33. doi:10.1016/j.ecolind.2013.11.024

Siebert S, Portmann FT, Döll P (2010) Global Patterns of Cropland Use Intensity. Remote Sensing 2:1625-1643. doi:10.3390/ rs2071625

Sleeter BM, Sohl TL, Bouchard MA, Reker RR, Soulard CE, Acevedo W, Griffith GE, Sleeter RR, Auch RF, Sayler KL et al (2012) Scenarios of land use and land cover change in the conterminous United States: utilizing the special report on 
emission scenarios at ecoregional scales. Glob Environ Chang 22:896-914. doi:10.1016/j.gloenvcha.2012.03.008

Sohl T, Sayler K (2008) Using the FORE-SCE model to project landcover change in the southeastern United States. Ecol Model 219:49-65. doi:10.1016/j.ecolmodel.2008.08.003

Stanchi S, Freppaz M, Agnelli A, Reinsch T, Zanini E (2012) Properties, best management practices and conservation of terraced soils in Southern Europe (from Mediterranean areas to the Alps): a review. Quat Int 265:90-100. doi:10.1016/j.quaint. 2011.09.015

Stoate C, Boatman ND, Borralho RJ, Carvalho CR, de Snoo GR, Eden P (2001) Ecological impacts of arable intensification in Europe. J Environ Manage 63:337-365. doi:10.1006/jema.2001. 0473

Stoate C, Báldi A, Beja P, Boatman ND, Herzon I, van Doorn A, de Snoo GR, Rakosy L, Ramwell C (2009) Ecological impacts of early 21 st century agricultural change in Europe-a review. J Environ Manage 91:22-46. doi:10.1016/j.jenvman.2009.07. 005

Stürck J, Poortinga A, Verburg PH (2014) Mapping ecosystem services: the supply and demand of flood regulation services in Europe. Ecol Indic 38:198-211. doi:10.1016/j.ecolind.2013.11. 010

Tayyebi A, Pijanowski BC, Linderman M, Gratton C (2014) Comparing three global parametric and local non-parametric models to simulate land use change in diverse areas of the world. Environ Model Softw 59:202-221. doi:10.1016/j.envsoft.2014. 05.022

Temme A, Verburg PH (2011) Mapping and modelling of changes in agricultural intensity in Europe. Agric Ecosyst Environ 140:46-56. doi:10.1016/j.agee.2010.11.010

Tscharntke T, Klein AM, Kruess A, Steffan-Dewenter I, Thies C (2005) Landscape perspectives on agricultural intensification and biodiversity-ecosystem service management. Ecol Lett 8:857-874. doi:10.1111/j.1461-0248.2005.00782.x

Tucker G, Allen B, Conway M, Dickie I, Hart K, Rayment M, Schulp C, van Teeffelen A (2013) Policy Options for an EU No Net Loss Initiative. Report to the European Commission. Institute for European Environmental Policy, London

UNECE-FAO (2011) The European forest sector outlook study II. 2010-2030. ECE/TIM/SP/28. United Nations, Geneva, Switzerland

Van Berkel DB, Verburg PH (2011) Sensitising rural policy: assessing spatial variation in rural development options for Europe. Land Use Policy 28:447-459. doi:10.1016/j.landusepol. 2010.09.002

Van Teeffelen AJA, Opdam P, Wätzold F, Hartig F, Johst K, Drechsler M, Vos CC, Wissel S, Quétier F (2014) Ecological and economic conditions and associated institutional challenges for conservation banking in dynamic landscapes. Landsc Urban Plan 130:64-72. doi:10.1016/j.landurbplan.2014.06.004

Van Vliet J, de Groot HLF, Rietveld P, Verburg PH (2015) Manifestations and underlying drivers of agricultural land use change in Europe. Landsc Urban Plan 133:24-36. doi:10.1016/j. landurbplan.2014.09.001

Van Zanten BT, Verburg PH, Espinosa M, Gomez-y-Paloma S, Galimberti G, Kantelhardt J, Kapfer M, Lefebvre M, Manrique R, Piorr A, Raggi M, Schaller L, Targetti S, Zasada I, Viaggi D
(2014) European agricultural landscapes, common agricultural policy and ecosystem services: a review. Agron Sustain Dev 34:309-325. doi:10.1007/s13593-013-0183-4

Verburg PH, Overmars KP (2009) Combining top-down and bottomup dynamics in land use modeling: exploring the future of abandoned farmlands in Europe with the Dyna-CLUE model. Landscape Ecol 24:1167-1181. doi:10.1007/s10980-009-9355-7

Verburg PH, Rounsevell MDA, Veldkamp A (2006) Scenario-based studies of future land use in Europe. Agric Ecosyst Environ 114:1-6. doi:10.1016/j.agee.2005.11.023

Verburg PH, Eickhout B, van Meijl H (2008) A multi-scale, multimodel approach for analyzing the future dynamics of European land use. Ann Reg Sci 42:57-77. doi:10.1007/s00168-007-01364

Verburg PH, van Berkel DB, van Doorn AM, van Eupen M, van den Heiligenberg HARM (2009) Trajectories of land use change in Europe: a model-based exploration of rural futures. Landsc Ecol 25:217-232. doi:10.1007/s10980-009-9347-7

Verburg PH, Tabeau A, Hatna E (2013) Assessing spatial uncertainties of land allocation using a scenario approach and sensitivity analysis: a study for land use in Europe. J Environ Manage 127:S132-S144. doi:10.1016/j.jenvman.2012.08.038

Verkerk PJ, Anttila P, Eggers J, Lindner M, Asikainen A (2011) The realisable potential supply of woody biomass from forests in the European Union. For Ecol Manage 261:2007-2015. doi:10.1016/ j.foreco.2011.02.027

Verkerk PJ, Mavsar R, Giergiczny M, Lindner M, Edwards D, Schelhaas MJ (2014) Assessing impacts of intensified biomass production and biodiversity protection on ecosystem services provided by European forests. Ecosyst Serv 9:155-165. doi:10. 1016/j.ecoser.2014.06.004

Verkerk PJ, Levers C, Kuemmerle T, Lindner M, Valbuena R, Verburg PH, Zudin S (2015) Mapping wood production in European forests. For Ecol Manage 357:228-238. doi:10.1016/j. foreco.2015.08.007

Wild Europe (2013) A working definition of European wilderness and wild areas. http://www.wildeurope.org/images/pdf/a-workingdefinition-of-european-wilderness-and-wild-areas.pdf. Accessed 30 May 2014

Winfree R, Gross BJ, Kremen C (2011) Valuing pollination services to agriculture. Ecol Econ 71:80-88. doi:10.1016/j.ecolecon. 2011.08.001

Wischmeyer WH, Smith DD (1978) Predicting rainfall erosion losses-a guide to conservation planning. US Department of Agriculture, Washington, DC

Woltjer GB, Kuiper MH (2014) The MAGNET Model: Module description. LEI Report 14-057. LEI Wageningen UR (University and Research centre), Wageningen, the Netherlands

Wu J, Feng Z, Gao Y, Peng J (2013) Hotspot and relationship identification in multiple landscape services: a case study on an area with intensive human activities. Ecol Indic 29:529-537. doi:10.1016/j.ecolind.2013.01.037

Zanchi G, Thiel D, Green T, Lindner M (2007) Forest area change and afforestation in Europe: critical analysis of available data and the relevance for international environmental policies. EFI Technical Report 24. European Forest Institute, Joensuu 